\title{
TOPONÍMIA, PODER E IDENTIDADE: UMA ABORDAGEM ACERCA DOS LOGRADOUROS CENTRAIS EM SÃO LUÍS, MARANHÃO
}

\author{
TOPONOMY, POWER AND IDENTITY: AN APPROACH ABOUT THE CENTRAL ADDRESSES IN SÃO LUÍS, \\ MARANHÃO
}

\author{
Luiz Eduardo Neves dos Santos ${ }^{1}$ \\ ${ }^{1}$ Universidade Federal do Maranhão (UFMA), Grajaú, MA, Brasil
}

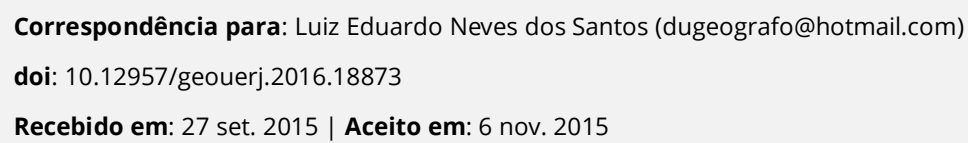

\section{RESUMO}

O trabalho apresenta uma discussão acerca da toponímia dos logradouros da cidade de São Luís, no que tange a sua mais antiga área de ocupação, o Centro. Investiga-se historicamente de que forma estes topônimos se formaram e por que alguns deles permanecem e outros não. A análise das relações existentes entre a linguagem toponímica e a identidade do grupo que se apropria dela é outra questão que merece destaque. Procura-se atestar ainda que a nomeação desses logradouros é um traço cultural inquestionável, por isso construtor e externalizador de identidades, mas também se constitui enquanto estratégia de poder, representado pela instituição de leis por parte do poder público que determina a maneira como acontecerá a nomeação. A metodologia de classificação dos topônimos é baseada a partir da proposta de Dick (1992). O objetivo da pesquisa é analisar a importância histórica e socioespacial dos topônimos, resgatando seus antigos nomes e procurando entender quais as reais motivações que o grupo dominante possui no ato da nomeação.

Palavras-chave: Toponímia; Logradouros; Identidade Cultural; Poder; São Luís.

\begin{abstract}
This paper presents a discussion on the addresses toponomy of São Luís City, in terms of its oldest area of occupation, the Center. It has been studied how these toponomies were historically formed and why some of them stay and others do not. The analysis of the existing connections between the toponimic language and the identity of the group, which appropriate of it, it's another topic that deserves to be emphasize. We try to certify that the designation oh these addresses is a undeniable cultural feature, being a identities constructor and externalizer, but also it constitute a strategy of power, represented by the establishment of laws of the part of public authorities who determine the way this designation will be. The toponomic classification methodology is based on the Dick proposal (1992). The objective of this research is analyze the historic and socio-spatial importance of the toponomies, recovering their ancient names and trying to understand which are the real motivations that the dominant group have at the nomination act.
\end{abstract}

Keywords: Toponymy; Addresses; Cultural identity; Power; São Luís. 


\section{INTRODUÇÃO}

(...) Na Rua do Sol me cego,/na Rua da Paz me revolto/na do Comércio me nego/mas na das Hortas floresço; /na dos Prazeres soluco/na da Palma me conheço/na do Alecrim me perfumo/na da Saúde adoeço/na do Desterro me encontro/na da Alegria me perco/na Rua do Carmo berro/na Rua da Direita erro/e na Aurora adormeço.

(Ferreira Gullar, Poema Sujo, 2009)

A poesia é uma das muitas formas de se evocar e homenagear determinada cidade. Exemplos não faltam. Dos versos de Manuel Bandeira em sua Evocação do Recife, aos de Drummond em Confidência do Itabirano, até o Romanceiro da cidade de São Luis de Bandeira Tribuzi, a cidade é resgatada do fundo da memória de seus poetas, de suas reminiscências ainda vivas, concretizadas na arquitetura de suas estrofes.

A Evocação do Recife de Manuel Bandeira representa um tempo da cidade de sua infância, a "Rua da União", a "Rua do Sol”, a "casa de seu avô" e "os pregões" são lugares e elementos cimentados na lembrança do poeta. Drummond, em Confidência do Itabirano, reconstrói na memória sua cidade natal, a pequena Itabira, revelando em seus versos a dor de sua saudade. Bandeira Tribuzi, no poema Romanceiro da cidade de São Luís, evoca os elementos físico-naturais de São Luís, dando a eles formas e sentimentos humanos. Os seus "rios como braços", o seu "mar com ânsia e raiva" e o "seu verde pulmão salgado" são maneiras figurativas, próprias da poesia, de dar vida à cidade.

A prosa é outra manifestação literária que entroniza as cidades. No início de seu Os tambores de São Luis, Josué Montello descreve os passos traçados por Damião pelas ruas da São Luís de 1915 . O palco, sob o manto negro faiscado com pontos brilhantes no ar, é representado pelo nostálgico e soturno ambiente amarelado dos lampiões acesos em cada esquina. Damião caminha pela rua das Cajazeiras, de São Pantaleão, da Inveja, do Mocambo, do Passeio e seus arredores, quase sempre inebriado pelo baticum dos tambores da Casa Grande das Minas. 
Ao abordar as relações sociais e de poder ocorridas no espaço urbano ludovicense, Montello descreve o cenário de seu romance de forma assaz ilustrativa. Sua referência às ruas, becos, praças, casarões e igrejas é convite tentador ao leitor-morador de São Luís voltar no tempo através da imaginação.

O presente artigo se deterá em discutir e analisar a toponímia da área central do município de São Luís a partir de um contexto geo-histórico. Investiga-se historicamente de que forma os topônimos foram formados e por que alguns deles permanecem e outros não. Procura-se atestar que a nomeação desses logradouros é um traço cultural, por isso construtor de identidades, mas também se constitui como estratégia de poder, representado pela instituição de leis por parte do poder público, que determina a maneira como acontecerá a nomeação.

\section{SOBRE TOPONÍMIA, LUGAR, TERRITÓRIO E IDENTIDADE}

Os nomes dos logradouros no Brasil estão em íntima relação com o cotidiano dos moradores que vivem (ou viveram) no lugar ou em seu entorno. Eles se constituem enquanto enunciados que nascem originalmente de forma espontânea, a partir de uma língua viva. Tal língua sofre variações ao longo do tempo histórico, podendo mudar de grafia ou mesmo entrar em desuso.

A toponímia é a disciplina que se preocupa com a procedência da significação dos nomes dos lugares, juntamente com a antroponímia (que cuida do significado dos nomes das pessoas), faz parte da Onomástica, ramo da Lingüística que se dedica aos nomes de indivíduos e lugares. De acordo com Dick (1990), o estudo da toponímia não se restringe à investigação lingüística ou etimológica, pois procura também a significação dos nomes dos lugares, extrapolando a esfera lingüística, dessa forma, leva em consideração também os aspectos geo-históricos, socioeconômicos e antropoculturais.

Os topônimos nascem a partir da fala dos sujeitos e a incorporação dos mesmos no cotidiano do grupo advém, quase sempre, de referências presentes na paisagem do lugar. Por isso, Isquerdo (1996, p. 81 82) afirmou que os topônimos são verdadeiros "fósseis lingüísticos, embora o signo toponímico esteja inserido no sistema lingüístico, a sua função não é de significar, mas de identificar os lugares. Serve de 
referencializador a realidade espacial do homem". As referências na paisagem podem ser representadas por alguém muito popular no local, por uma capela ou igreja consagrada a algum santo, por um acidente geográfico ou, ainda, por elementos da natureza característicos da localidade.

O lugar é indubitavelmente um resultado da experiência humana. Sua existência seria explicada pela maneira como as pessoas o percebem e lhe dão significado, que por sua vez é constituído e apreendido nas relações cotidianas. Para Buttimer (1985 apud LEITE, 1998, p. 10), o "lugar é o somatório das dimensões simbólicas, emocionais, culturais, políticas e biológicas”. Neste sentido, o lugar é caracterizado como um "mundo de significado organizado" (TUAN, 2013, p.198). É nele que deve existir uma sensação de familiaridade entre os indivíduos e de enraizamento para com o ambiente circundante, disso decorre sua forte carga subjetiva.

Outro ente espacial, não menos importante que o lugar, é o território. Seu entendimento é semelhante ao de lugar, chegando até mesmo a confundir-se com ele em alguns aspectos. Milton Santos afirma que no início da relação homem/meio, o território era um forte componente de identidade (SANTOS, 2000, p. 62), ou seja, o sentido de pertencimento do grupo ao ambiente no qual estavam inseridos, produzia uma idéia própria de domínio. Para Holzer (1997, p. 83-84) “o território traduz-se como um conjunto de lugares, onde se desenvolvem laços afetivos e de identidade a determinado grupo social", ou seja, este não precisa ser necessariamente fechado e rígido. Sua existência é condição básica para a formulação de um mundo pessoal ou intersubjetivo. Segundo Haesbaert (1999, p. 185-186),

\footnotetext{
O território envolve não somente um "ter" mediador de relações de poder (político-econômico) sobre parcelas do espaço, ele compõe também o "ser". Ao mesmo tempo prisão e liberdade, lugar e rede, fronteira e coração, o território de identidade pode ser uma prisão que esconde e que oprime ou uma rede que se abre e se conecta a um coração que emana poesia e novos significados.
}

Assim como o lugar, o território produz uma enorme carga subjetiva, onde seus habitantes criam fortes laços de identidade e de apego a uma determinada porção do espaço. Com isso, ao apropriar-se de um espaço qualquer, os grupos sociais desenvolvem características comuns, construindo no seu cotidiano, relações afetivas com o seu território, que por sua vez é transformado de acordo com as vontades e anseios do próprio grupo. 
A noção de "território utilizado" proposta por Santos (2001, p. 247) nos parece reveladora de processos de identificação próprias dos sujeitos, já que o território por si só não diz nada, mas é o seu uso que gera reconhecimento e dá valor ao espaço. É por isso, por exemplo, que alguns nomes de logradouros no Brasil existem apenas no papel da legislação, já que o grupo se utiliza de outros topônimos no cotidiano. Então, a identidade é um complicado mosaico de relações entre o sujeito e o mundo, no qual, têm no lugar e no território suas maiores expressões.

A identidade forma-se da tríade lugar-topônimo-habitante, traduzindo-se como mediação entre o sujeito e o contexto da sua vida, onde mora com sua família, sua relação com seus vizinhos e amigos, os ambientes que freqüenta (escola, trabalho, igreja, etc.), tudo isso faz parte da construção da personalidade e da identidade de um indivíduo ou grupo. A rua é o primeiro ambiente com que as pessoas se deparam ao sair de casa. Em relação a alguns locais, esta pequena porção do espaço não pode ser entendida apenas como lugar de passagem de pessoas ou de veículos. As ruas em algumas circunstâncias apresentam uma série de significados, ao mesmo tempo em que separam, podem unir, geram encontros, são utilizadas de várias maneiras, o jogo de futebol, as festas carnavalescas, as manifestações da cultura popular, tudo isso acontece por essas vias que cortam a cidade.

Nesse contexto, os topônimos assumem uma função essencial, a de identificação para o grupo que se utiliza deles. Esses nomes apresentam uma forte relação de subjetividade com esse grupo, havendo uma significação, uma relação de complementaridade entre o lugar e o habitante mediada pelo topônimo. A nomeação dos lugares é um traço cultural inconfundível, mas é também uma estratégia de poder. Ela é uma prática social e uma prática discursiva. Para Tuan (1975 apud LEITE, 1998. P. 12), "dar nome a um lugar é dar seu explícito reconhecimento, isto é, reconhecê-lo conscientemente ao nível da verbalização". Como já foi mencionado, o topônimo é um alicerce na construção de identidades e por mais que alguns nomes tentem se manifestar por imposição, seu uso implica certo consentimento.

Para Gohn (2006) a identidade de um grupo se constrói a partir de um conjunto de percepções e visões de mundo que transparece no seu processo de experiência histórica, ao atuar coletivamente, aliados as representações simbólicas que também constroem ou adotam. Assim é possível afirmar que toda 
identidade é produzida socialmente por meio de uma atividade discursiva e imaginária. Reforça-se, portanto, seu caráter cultural.

Dessa maneira, cidade é um território composto por imagens diversas, um bairro, uma praça, uma rua, uma igreja, uma casa são elementos que unem certo número de pessoas propiciando a criação de múltiplas representações e identidades. Ferrara (1990) assinala que as mudanças econômicas e sociais criam marcas no meio urbano, traduzidas por imagens que têm como significado o conjunto de valores, hábitos, desejos que unem através dos tempos, o cotidiano dos homens. A cidade, o bairro onde um indivíduo morou e cresceu, as pessoas com quem brincou e conviveu, as suas atividades de lazer, onde estudou, que atividades profissionais que desenvolve, enfim as influências que sofreu, são fatores cruciais na diferenciação de concepções e visões de mundo.

\section{BREVE HISTÓRICO DOS TOPÔNIMOS EM SÃO LUÍS}

A origem da ocupação européia em São Luís nos remete ao fim do século XVI e início do século XVII com a chegada de embarcações vindas da França. Os franceses tentaram estabelecer nestas terras a chamada França Equinocial, uma "frustrada tentativa de instituir uma colônia no norte do Brasil, cuja extensão não se resumiria à Ilha do Maranhão. Pela iniciativa do reconhecimento do continente até o Amazonas, presume-se a grande extensão pretendida por eles para sua futura colônia" (LACROIX, 2008, p. 39).

Apesar de não atingirem seu objetivo principal, permitiu ao francês, Senhor de La Ravardière, Tenente-General do Rei da França no Brasil, “fundar” São Luís em 1612. A construção do discurso sobre a fundação de São Luís pelos franceses foi iniciada no fim do século XIX por uma minoritária elite intelectual na cidade. O Maranhão, que vivia um período de decadência e marasmo socioeconômico, precisava da criação de um mito para que sua população pudesse orgulhar-se de seu passado. Foi então inventada a ideia de que os franceses fundaram o lugar, já que nessa época o modelo cultural da França era universal e São Luís não fugia à regra. Outra questão que alavancou 
esse mito fundacional foi o resgate da ideia de Atenas Brasileira, na qual São Luís foi concebida como berço de homens de letras. Lacroix (2008) chamou esse fenômeno de "ideologia da singularidade".

Existem duas correntes opostas no Maranhão sobre a origem do topônimo 'São Luís', a mais difundida considera que o nome é uma referência a memória eterna a Luís XIII, Rei da França e de Navarra. Outra corrente admite que o nome "invoca o querido santo francês Luís IX, canonizado muito antes do descobrimento do Brasil, muito reverenciado pelos fiéis portugueses" (LACROIX, 2008, p. 87).

Os franceses, ao se instalarem na Ilha do Maranhão, escolheram um promontório localizado na baía de São Marcos, entre as embocaduras dos rios Anil e Bacanga. Neste lugar, de topografia suavemente elevada, foi construído um Forte, que devido a sua posição geográfica e estratégica favorável, facilitava a defesa contra possíveis ataques de embarcações inimigas que adentravam o continente. Assim, os gauleses quando chegaram à ilha, estreitaram as ligações com os índios tupinambás, que já habitavam esta região antes da chegada dos brancos. O nascimento de São Luís deriva assim da construção de um Forte, situado em ponto estratégico com vista para o mar, rota de entrada de embarcações. O Forte compreende o atual Palácio do Governo do Estado do Maranhão, situado na Avenida Dom Pedro II.

No fim do ano de 1615, na chamada Batalha de Guaxenduba, os franceses foram derrotados e expulsos pelos portugueses sob o comando de Jerônimo de Albuquerque, iniciando oficial e efetivamente a colonização portuguesa em terras maranhenses. Um desafio que se apresentou aos portugueses foi a necessidade de pessoas para ocupar e trabalhar em prol do território recém "conquistado".

O traçado urbano inicial da capital maranhense é atribuído por alguns estudiosos ao arquiteto e engenheiro militar lusitano Francisco Frias de Mesquita. Este traçado, de linhas retas, em forma de tabuleiro de xadrez, é visível no território da Praia Grande, área tombada pela UNESCO como Patrimônio da Humanidade. Por volta da metade dos anos seiscentos, as poucas casas presentes na cidade eram, em sua maioria, de pindoba. Nos fins do século XVII, segundo o historiador José Ribeiro 
do Amaral, as edificações passaram a ser construídas de taipa de Pilão com telha vã sobre madeira mal polida, contando São Luís com quinhentas casas (AMARAL, 2003).

Estas primeiras ocupações, representadas por pequenos núcleos, se localizavam em pontos mais favoráveis à coletividade, que através de doações feitas pelo Senado da Câmara de São Luís, encontravam-se nas proximidades do Forte, do cais do Porto, de lugares sagrados e igrejas e das fontes de água.

Ribeiro do Amaral (2003, p. 76), afirmou que até o "ano e 1733 as ruas da pequena São Luís não tinham nomeação, havia apenas referências a elas", isto é, as denominações se ligavam a algum objeto característico da paisagem, a algum acontecimento, ou mesmo a um nome de alguém muito conhecido no lugar. Mas isso não é de se estranhar, muitas cidades no Brasil possuem logradouros com nomes que passaram incólumes por décadas, séculos e surgiram a partir de referências contidas na paisagem, transmitidas entre gerações por tradição oral.

No século XVIII, a malha urbana da capital maranhense resumia-se ao Largo do Carmo, Praia Grande e Desterro (GOMES, 1988). Este crescimento deu-se de forma espontânea, não obedecendo a um plano pré-estabelecido, causando uma grande diferença entre suas ruas e edificações. Do século XVIII até o primeiro quarto do século XX a cidade cresce de forma tímida, o local hoje conhecido como Anel Viário era o mais urbanizado, outras ocupações mais rarefeitas situavam-se ao longo do São Francisco, do Itaqui-Bacanga e ao longo do caminho grande, uma antiga estrada que se confundia com a Rua Grande, este caminho ligava a antiga zona urbana da cidade às áreas mais distantes da Ilha do Maranhão.

A segunda metade da década de 1930 foi marcada pela indicação de um Interventor Federal no Maranhão - Paulo Martins de Sousa Ramos - que tinha com o objetivo orientar atividades para o bem-estar da população através da melhoria dos serviços públicos, ou seja, o Maranhão e a cidade de São Luís precisavam de obras que atendessem as necessidades de sua população. 
Em 1937, Paulo Ramos inicia um programa de reforma e construção de estradas no interior do Estado e em São Luís. A cidade passa por um pequeno e limitado surto de modernização. Sua emergente malha urbana se diferenciaria daquela que atendia os padrões do século XIX. A cidade então cresceu a partir chamado caminho grande, que se tornou o principal sistema viário da capital.

Desta forma, o crescimento urbano de São Luís tem como uma de suas maiores expressões a ocupação do eixo Centro-Anil. Segundo Gomes (1988), nas décadas de 1920 e 1930, São Luís possuía um lento crescimento da área urbana, permitindo com que a cidade atraísse recursos direcionados à urbanização, como algumas tímidas melhorias em saúde, educação, transporte, energia e saneamento. A partir da década de 1940 a cidade "expande-se numa faixa de aproximadamente 13 quilômetros de extensão" (GOMES, 1988, p. 21), sendo que a topografia pouco favorável, situada no divisor de águas dos dois principais rios da ilha, fez com que este crescimento se direcionasse aos manguezais.

De acordo com Ribeiro Júnior (2001, p. 89), "entre os anos de 1940 à 1970, a cidade recebeu milhares de migrantes vindos do campo, fazendo com que as áreas da Avenida Getúlio Vargas (antigo caminho grande) fossem ocupadas". Daí surgiram as localidades do Areal (atual bairro do Monte Castelo), Matadouro (atual bairro da Liberdade), Cavaco (atual bairro de Fátima), João Paulo, Filipinho, Anil, entre tantos outros. A partir da década de 1970 e 1980, com a construção da ponte sobre o rio Anil e da barragem do Bacanga, a cidade se expandiu para outras áreas, possibilitando o surgimento de uma série de conjuntos habitacionais e bairros.

A expansão urbana da cidade ensejou a criação de novos nomes aos logradouros. Segundo Di Tizio (2007), raras são as leis municipais que estabelecem regras para a motivação toponímica. Em São Luís, até a metade da década de 1970 não houve uma política efetiva que estivesse voltada para 0 estabelecimento de regras para nomear logradouros. Houve sim, algumas tentativas do poder público municipal, através da aprovação de leis e decretos, de se modificar o nome de alguns logradouros consagrados popularmente. Geralmente o que acontecia era a substituição de um nome popular pelo nome de alguma personalidade (antropotopônimo). Exemplos disso são as leis nํ․ 300/51 e 334/51 
que, respectivamente, deram o nome de Saturnino Belo à antiga Rua da Carioca e denominou de Elídio Jansen a via pública conhecida pelo nome de Amendoeira.

Um marco importante sobre a regulamentação dos nomes de logradouros na cidade foi a aprovação da lei municipal $n^{\circ}$. 2.151/75, que determinava o estabelecimento de critérios para a nomenclatura dos logradouros na capital maranhense. Aprovada na gestão do Prefeito Haroldo Tavares, estabeleceu regras para a nomeação logradouros públicos (ruas, becos, praças, etc.). No anexo da lei constam os nomes oficiais dos logradouros, os seus nomes antigos, o memorial descritivo indicando onde eles iniciam e terminam e o histórico de cada um deles.

A cidade do início do século XXI é muito diferente da velha cidade, antes pequena e limitada. São Luís, antes provinciana, dá lugar a uma grande aglomeração, a cidade é detentora de problemáticas estruturais graves, como pobreza, desemprego, violência, poluição ambiental, consequências da ausência de planejamento urbano e de investimentos maciços em Educação e Saúde por parte do poder público. Com quarenta anos de existência, a lei 2.151/75 tornou-se obsoleta em face da quase triplicação da população da cidade e da exacerbada expansão de seu espaço urbano.

\section{CAMINHOS DA PESQUISA E LOCALIZAÇÃO DA ÁREA DE ESTUDO}

A pesquisa teve apoio dos dados levantados pelo Instituto da Cidade, Pesquisa e Planejamento Urbano e Rural (INCID) para a revisão da Lei de Toponímia do município de São Luís (2.151/75) nos anos de 2008/2009. A revisão da legislação contou com a realização de audiências públicas e sensibilizações com os moradores dos bairros envolvidos. Foi constituída uma Comissão Toponímica, através do Decreto 33.607 em 2008 e foi redigido o texto do projeto de Lei.

Para a verificação das informações, os pesquisadores do INCID trabalharam com pesquisa de campo, documental e bibliográfica. Sobre a pesquisa de campo, obtiveram-se dados que compuseram o histórico. Foi feito um acordo de cooperação entre a Prefeitura de São Luís e a Universidade Estadual do Maranhão (UEMA), o que possibilitou a utilização do trabalho de estagiários nos levantamentos. 
Foram aplicados dois tipos de questionários: um técnico-urbanístico, que verificou as condições físicas do logradouro; outro, sociocultural, que procurou levantar com os moradores e trabalhadores, os nomes pelos quais os logradouros eram conhecidos, o porquê destas denominações, além dos locais de início e término de cada logradouro.

Sobre a pesquisa documental e bibliográfica, houve o levantamento de obras e dados em publicações que versam sobre o tema "toponímia de logradouros de São Luís", encontrado em livros, artigos científicos, jornais, revistas, ementários, diários oficiais, dentre outros. O levantamento de dados em arquivos públicos e particulares. As buscas na rede mundial de computadores foram de grande valia também.

A tarefa de nomear logradouros em uma cidade como São Luís não constitui tarefa das mais simples, principalmente quando se trata de um espaço de ocupação bastante antigo. Os nomes de logradouros nascem de forma espontânea e emanam do cotidiano de um dado grupo em relação ao lugar onde vivem. As referências contidas na paisagem do lugar contribuem muito na incorporação determinados topônimos.

É muito comum a existência de dois ou mais nomes para um mesmo logradouro na cidade, por isso foram estabelecidos critérios para a escolha dos 337 topônimos encontrados na pesquisa. No universo dos logradouros da área citada existe grande variedade de tipologias toponímicas. Intelectuais, políticos, santos, religiosos, datas comemorativas, pessoas representativas do lugar, nomes populares, eis alguns dos tipos mais comuns de nomeações. O principal critério utilizado pelos pesquisadores do INCID para a escolha do nome definitivo do logradouro foi a quantidade de vezes que foi citado pelos entrevistados e moradores do lugar. Geralmente os nomes mais citados são os mais aceitos pela comunidade.

Alguns nomes estão consagrados no imaginário popular do ludovicense e por mais que alguns outros nomes tenham se manifestado por imposição, seu uso requer certa aceitação por parte do grupo. Alguns topônimos servem de exemplo, como a Praça da Alegria, que já possuiu as nomeações de 
Sotero dos Reis e 13 de maio, mas permanece com o nome Alegria por força da memória popular.

Outro exemplo é a Rua Grande, que já se chamou Avenida Osvaldo Cruz, mas a população pouco utiliza o nome do médico e sanitarista para referir-se ao logradouro. Assim acontece também com o Beco Catarina Mina (antiga Rua Djalma Dutra), a Rua do Egito (antiga Rua Tarquínio Lopes), a Rua do Sol (antiga Rua Nina Rodrigues), dentre muitos outros.

A partir dos dados coletados no INCID com informações sobre os 337 logradouros do Anel Viário (figura 1) de São Luís, construiu-se uma divisão em grupos, uma tipologia de topônimos baseada no estudo de Dick (1992, p. 31-34), na qual estabelece 27 (vinte e sete) taxionomias, sendo 11 (onze) referentes ao ambiente físico e 16 (dezesseis) ligadas aos aspectos socioculturais e históricos.

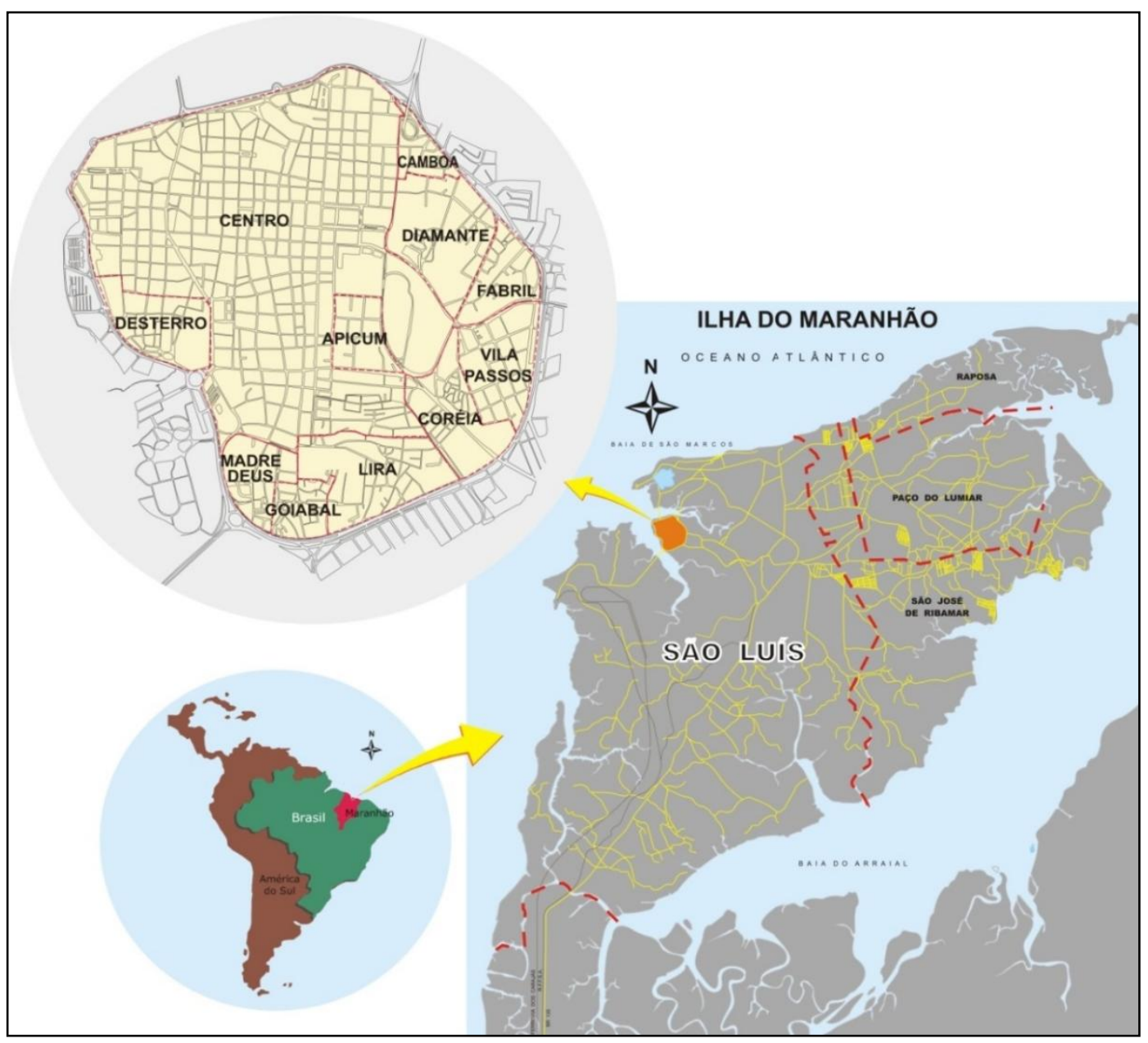

Figura 1. Localização da região do Centro antigo de São Luís.

Fonte: Elaborado pelo autor, 2013. 
Taxonomias de Natureza Física: 1. Astrotopônimos - Referente aos nomes de corpos celestes (ex: Rua da Estrela); 2. Cardinotopônimos - Relativo a posições geográficas em geral (ex: Rua do Norte); 3. Cromotopônimos - Referem-se à escala cromática (ex: Beco Escuro); 4. Dimensiotopônimos Relativos as características dimensionais dos acidentes geográficos como largura, comprimento, extensão, altura e profundidade (ex: Rua Grande); 5. Fitotopônimos - Ligado a plantas e vegetais (ex: Rua da Mangueira); 6. Geomorfotopônimos - Referente às formas topográficas, elevações no terreno, depressões e formações litorâneas (ex: Montanha Russa); 7. Hidrotopônimos - Referentes à acidentes hidrográficos em geral (ex: Fonte do Ribeirão); 8. Litotopônimos - Ligados aos minerais e componentes do solo (ex: Fonte das Pedras); 9. Meteorotopônimos - remete a idéia de fenômenos produzidos na atmosfera terrestre (ex: Praça do Trovão); 10. Morfotopônimos - Relativo aos topônimos cujo sentido lembra as formas geométricas (ex: Rua da Curva); 11. Zootopônimos - Entre as fontes motivadoras de topônimos é comum, no Brasil, a presença de animais (ex: Rua da Cotovia).

Taxonomias de Natureza Antropocultural: 1. Animotopônimos (ou Nootopônimos): topônimos relativos à vida psíquica, à cultura espiritual. (ex: Praça da Saudade); 2. Antropotopônimos: topônimos relativos aos nomes próprios individuais (ex: Praça Odorico Mendes); 3. Axiotopônimos: topônimos relativos aos títulos e dignidades que acompanham nomes próprios individuais (ex: Avenida Senador Vitorino Freire); 4. Corotopônimos: topônimos relativos a nomes de cidades, países, estados, regiões e continentes (Rua Belo Horizonte); 5. Cronotopônimos: topônimos relativos aos indicadores cronológicos representados pelos adjetivos novo(a), velho(a) (ex: Rua Cidade Nova); 6. Ecotopônimos: topônimos relativos às habitações em geral. (ex: Rua do Mocambo); 7. Ergotopônimos: topônimos relativos aos elementos da cultura material. (ex: Beco das Canoas); 8. Etnotopônimos: topônimos relativos aos elementos étnicos isolados ou não (ex: Avenida dos Africanos); 9. Dirrematopônimos: topônimos constituídos de frases ou enunciados lingüísticos. (ex. Passa e Fica); 10. Hierotopônimos: topônimos relativos a nomes sagrados de crenças diversas, a efemérides religiosas, às associações religiosas e aos locais de culto (ex: Largo dos Evangélicos). Essa categoria subdivide-se em: 10.1 Hagiotopônimos: nomes de santos ou santas do hagiológio católico romano (ex: Rua Nossa Senhora da Guia), 10.2 Mitotopônimos: entidades mitológicas (ex: Rua Zeus); 11. 
Historiotopônimos: topônimos relativos aos movimentos de cunho histórico, a seus membros e às datas comemorativas (ex: Rua 21 de Abril); 12. Hodotopônimos: topônimos relativos às vias de comunicação urbana ou rural (ex: Caminho da Boiada); 13. Numerotopônimos: topônimos relativos aos adjetivos numerais (ex: Dois vizinhos); 14. Poliotopônimos: topônimos relativos pelos vocábulos vila, aldeia, cidade, povoação, arraial (ex: Vila Conceição); 15. Sociotopônimos: topônimos relativos ás atividades profissionais, aos locais de trabalho e aos pontos de encontro da comunidade, aglomerados humanos. (ex: Travessa dos Vidraceiros); 16. Somatopônimos: topônimos relativos metaforicamente ás partes do corpo humano ou animal (ex. Braço do Trombudo).

\section{OS TOPÔNIMOS EM SÃO LUÍS: UM PERFIL DOS LOGRADOUROS CENTRAIS E SUA IDENTIDADE}

No Brasil, as regiões urbanas possuem uma quantidade maior de logradouros com taxonomias de natureza Antropocultural, isso é explicado pelo fato de existir nesses lugares paisagens com objetos técnicos variados, espaços compostos de monumentos, edifícios, muros, shoppings, cada vez mais distante de uma realidade físico-natural. Como já mencionado, a escala de análise é o chamado Anel Viário, região com 337 logradouros e que se divide quanto às taxonomias da seguinte forma:

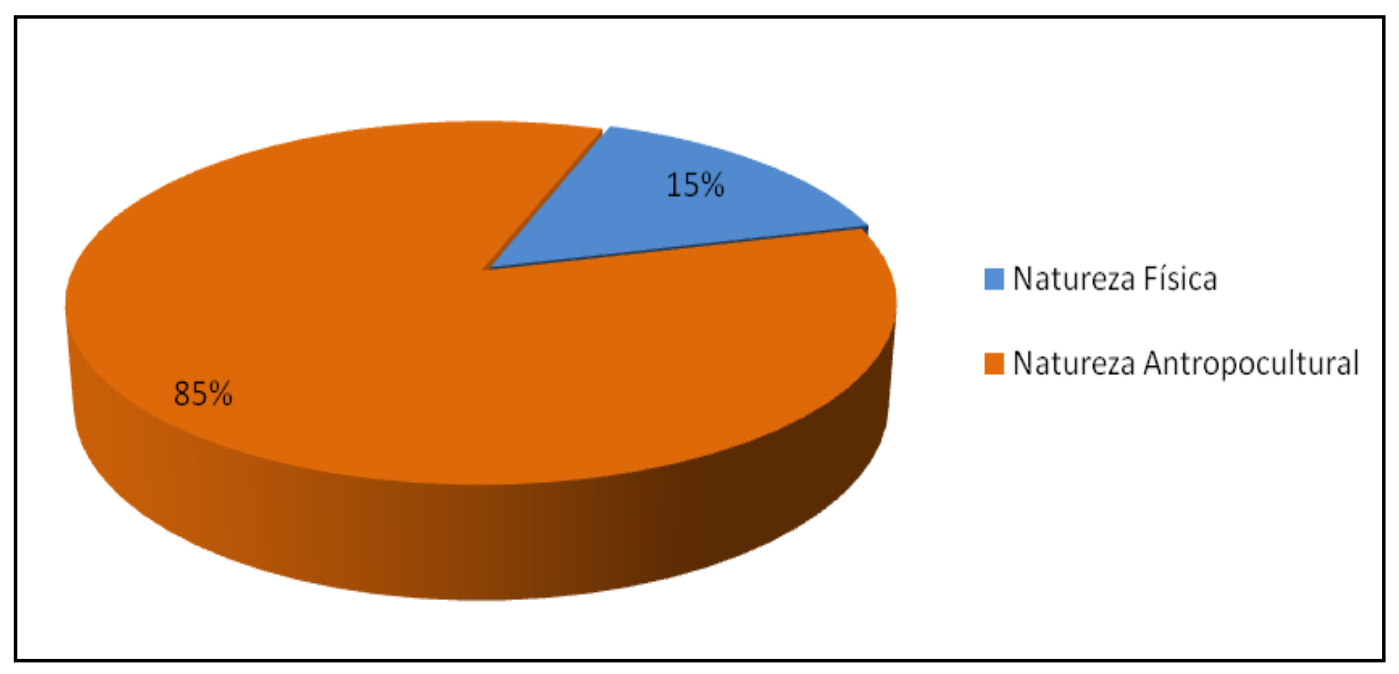

Figura 2. Natureza dos topônimos no centro antigo de São Luís.

Fonte: Elaborado pelo autor, 2013 
Embora em número bem menor, as taxes de natureza física se relacionam as características presentes na paisagem da cidade, que é uma ilha continental bem próxima do equador. Encontramos assim as denominações como Avenida Beira-Mar, Rua do Apicum, Rua do Coqueiro, Praça da Praia Grande, exemplos de alguns topônimos relacionados aos ambientes litorâneos. Assim como Rua das Cajazeiras, Rua da Mangueira e Rua da Amendoeira, exemplos de espécies de árvores comuns em regiões de climas tropicais.

O alto grau de urbanização da área de estudo, devido a fatores históricos mais antigos de ocupação, faz com que haja uma incidência elevada de taxonomias de natureza antropocultural. A partir da proposta formulada Dick (1992), pode-se dividir os topônimos inseridos no Anel Viário em São Luís da seguinte forma:

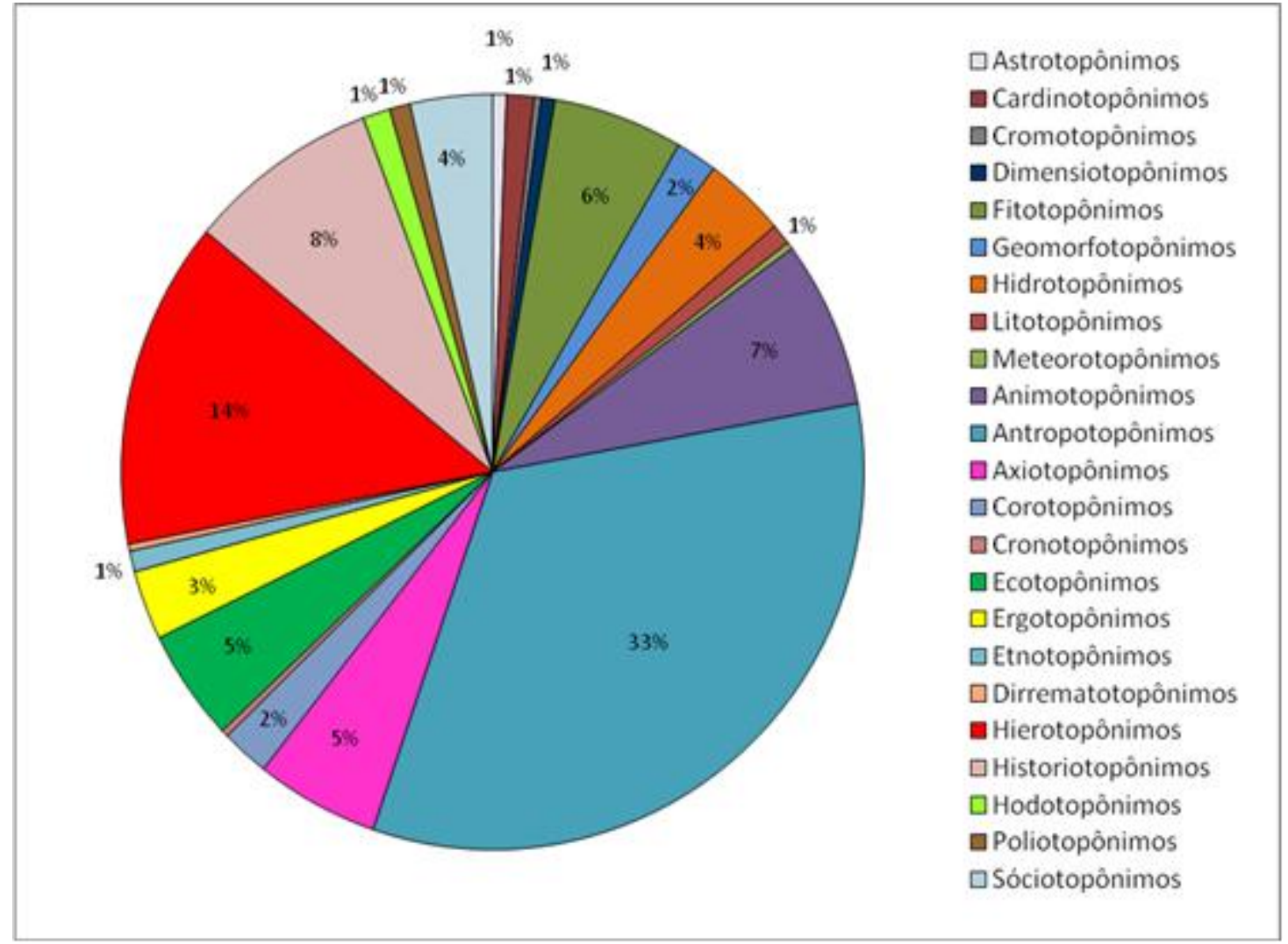

Figura 3. Taxonomias dos Logradouros centrais em São Luís. Fonte: Elaborado pelo autor, 2013.

É possível observar na Figura 3 que as maiores incidências taxonômicas no Centro antigo de São Luís são os Antropotopônimos (33\%), os Hierotopônimos (14\%), os Historiotopônimos (8\%), os Animotopônimos (7\%) e os Fitotopônimos (6\%), sendo este último o único de natureza física. 
A partir desta constatação, foi escolhido dissertar sobre as duas taxonomias mais frequentes, os Hierotopônimos, que têm nos santos católicos sua maior incidência e os antropotopônimos, representados principalmente por intelectuais ligados às letras e ao poder.

Tanto os Hierotopônimos quanto a sua subdivisão em Hagiotopônimos, nomes ligados ao hagiológio católico, são muito encontrados na região central de São Luís. São topônimos ligados à fé cristã como Rua Bom Jesus, Praça da Bíblia, Largo dos Evangélicos e também nomes de Santos católicos, como Largo do Desterro (Figura 4), Rua São Tomás de Aquino, Travessa São Pedro, Travessa São José e tantas outras. As referências constantes a santos católicos nos logradouros da cidade são a prova da marca indelével de colonização portuguesa em São Luís.

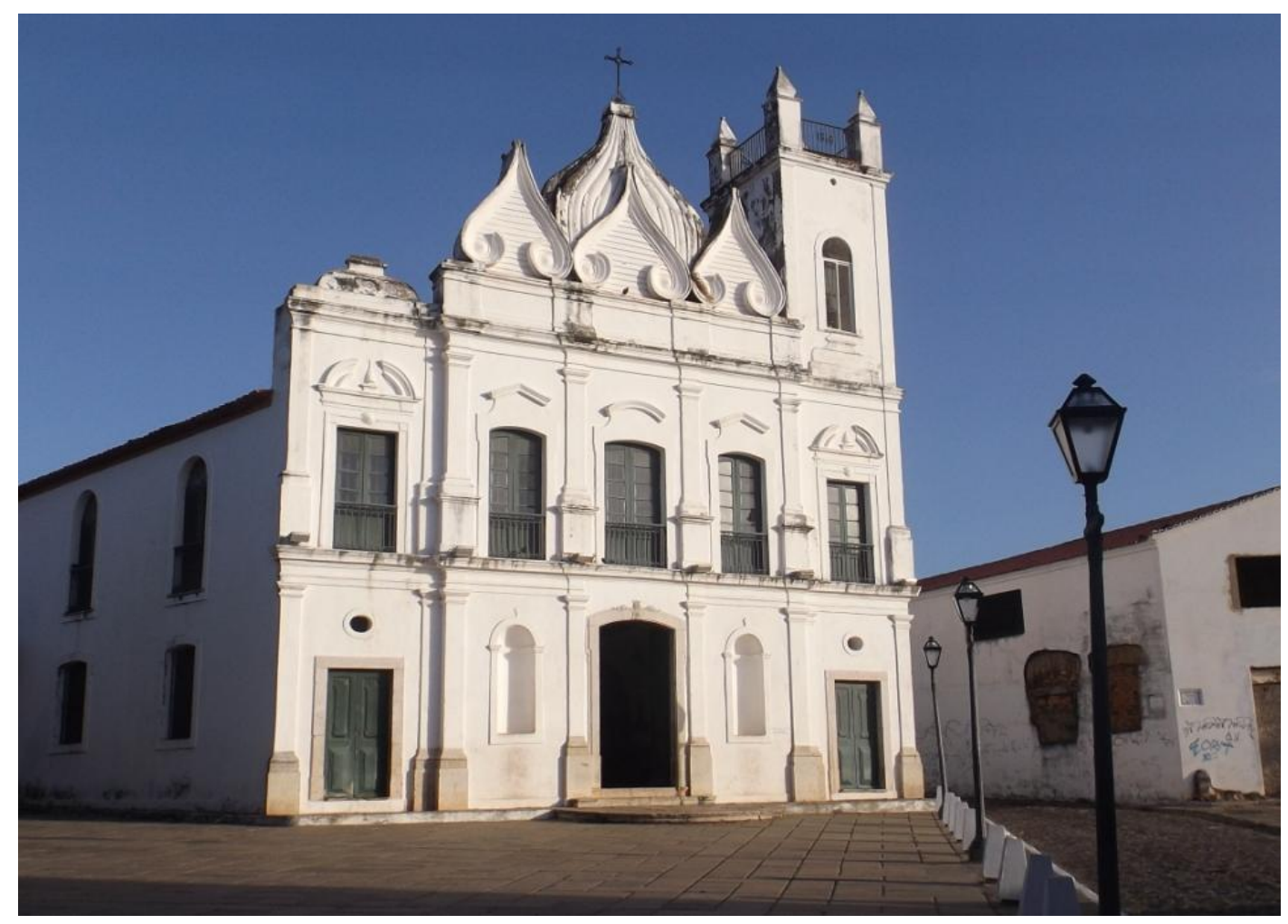

Figura 4. Largo e Igreja do Desterro em São Luís.

Fonte: O autor (2015).

É necessário afirmar que a maioria dos logradouros com nomes de santos está diretamente relacionada à apropriação do território pelos habitantes do lugar por símbolos e monumentos católicos, a exemplo da imagem de São Sebastião localizada em um oratório no Largo de mesmo nome no bairro da Madre 
Deus. De acordo com Isquerdo (1996, 142-143), “dar o nome de um santo a alguém ou a algum lugar significa colocar esse ser ou esse local nomeado sob os cuidados específicos desse santo". A grande maioria dos hagiotopônimos da área central de São Luís fica nas proximidades dos templos e igrejas, representados por ruas, travessas, mas, sobretudo por largos e praças.

Para Choay (2006, p. 18), "chamar-se-á monumento tudo o que o quer for edificado por uma comunidade de indivíduos para rememorar ou fazer que outras gerações de pessoas rememorem acontecimentos, ritos, mitos ou crenças". As igrejas do centro são exemplos emblemáticos, já que se inscrevem no lugar de forma a fortalecer os laços afetivos da comunidade.

Rosendhal (2005, p. 198) assinala que "o território é ocupado, e dessa forma, consagrado, protegido e reconhecido pela comunidade". As igrejas e a religião possuem grande importância para o território, pois são fundadoras de identidades e se exprimem através de símbolos, como por exemplo, a estrutura física das igrejas e suas imagens, que passam a representar um lugar sagrado para seus moradores, que se dirigem com regularidade para orar, rezar, comungar e pedir a Deus a remissão de seus pecados. Os monumentos sagrados no centro de São Luís têm um papel primordial na formação e nomeação de logradouros do entorno.

\section{A PLÊIADE DA INTELECTUALIDADE INSCRITA NOS LOGRADOUROS}

O lugar objeto deste artigo passou ao longo do tempo por mudanças drásticas no que tange a nomeação de seus logradouros, sobretudo a partir da segunda metade do século XIX e com mais força no início do século XX. Desta forma, os topônimos de natureza física na cidade foram gradativamente substituídos, via decisão/imposição do poder público, por topônimos de natureza antropocultural, sobretudo de intelectuais, maranhenses ou não, como escritores (Rua Humberto de Campos, Rua Graça Aranha), poetas (Praça Gonçalves Dias, Praça Catulo da Paixão Cearense), Jornalistas (Praça João Lisboa, Rua Vicente de Carvalho), Juristas (Rua Godofredo Viana, Avenida Rui Barbosa), médicos (Rua Netto Guterres, Avenida Silva Maia) e Políticos (Praça Benedito Leite, Parque Urbano Santos), todos membros de uma elite minoritária de São Luís e do Brasil. 
É preciso entender um pouco como se fundou o mito e a tradição em terras maranhenses da cultura ligada as letras. O Maranhão vivenciou um período de grande desenvolvimento econômico na segunda metade do século XVIII, época em que a Companhia Geral do Grão Pará e Maranhão fomentou grandes investimentos na cultura do arroz e do algodão, gerando a absorção de grande riqueza por parte de determinadas famílias. Para Rossini Corrêa (2012),

\begin{abstract}
A ascensão econômica resultante da presença da companhia mercantil, cuja similar paraibana foi nefasta, no dizer de José Américo de Almeida, articulou uma espécie de prosperidade suficiente para o Maranhão disputar, com Bahia e Minas Gerais, a primazia de ter filhos seus estudando em universidades européias, básica, mas não exclusivamente, em Portugal. Assim floresceram os bacharéis em leis, letras, teologia, matemática e, mais raramente, medicina e engenharia. Não faltaram os formandos em filosofia. Eis a razão histórica da cultura maranhense, produto espiritual de uma sociedade de senhores e de escravos: a brasileira.
\end{abstract}

As palavras de Corrêa chamam atenção para a contradição acintosa da sociedade brasileira, ou seja, a oposição senhor/escravo, que encontra no Maranhão uma de suas mais fortes representações. 0 abismo a separar senhores e escravos tornou-se mais largo a partir da formação intelectual e cultural européia dos filhos de integrantes da aristocracia local. Tal fato propiciou um ambiente favorável a esses indivíduos a exercerem cargos na administração pública e a ingressarem em carreiras como o jornalismo e a política.

Nas primeiras décadas do século XIX, momento de arrefecimento da rizicultura e também da cultura do algodão, houve a formação do chamado Grupo Maranhense (1832-1868), composto por nomes de envergadura nas letras, a exemplo de João Lisboa, Gonçalves Dias, Odorico Mendes, Gomes de Sousa e Sotero dos Reis.

Surge então na primeira metade dos oitocentos a denominação de Atenas Brasileira para a cidade de São Luís. Para Oliveira (2006, p. 139), foi uma proposta que teve por objetivo "incutir na sociedade a imitação dos padrões clássicos da civilização ocidental, de se tornar um referencial identitário, buscar legitimidade intelectual, notoriedade e evocar nomes-símbolos, como a terra e, sobretudo o homem." Na realidade surge uma espécie de estereótipo da sociedade ludovicense, como se toda ela fosse 
letrada, mas a realidade é que a grande maioria da população era analfabeta. Para Lacroix (2008, p. 67), o cognome Atenas Brasileira

Rendeu ao Maranhão e ao maranhense o estatuto de ateniense, generalizando o que era mais imaginário que real, dissimulando a divisão concreta e efetiva daquela sociedade elitista e preconceituosa. Aludida mitologia cultivada pela classe dominante foi repetida, acreditada e transmitida e toda a sociedade (...) A ideia de que a Atenas Brasileira era especial e superior foi aceita também pelos menos favorecidos, e o Maranhão em seu declínio econômico e cultural, por várias décadas foi nutrido por este orgulho.

A concepção de Atenas Brasileira, entendida como mito por autores como Corrêa (1993) e Borralho (2009), figurou muitos anos no imaginário do ludovicense, pois proporcionava à população uma espécie de orgulho e diferenciação perante outras regiões do Brasil. Nos fins do século XIX surgiu outro grupo de intelectuais a partir da Oficina dos Novos (1901) e da Academia de Letras (1908). Os nomes mais representativos desse grupo foram Antônio Lôbo e Ribeiro do Amaral (LACROIX, 2008). Mas faziam parte desse grupo nomes importantes como Godofredo Viana, Viriato Corrêa, Barbosa de Godóis, Fran Paxeco, Alfredo de Assis, Clodoaldo Freitas, Astolfo Marques, dentre outros.

Os novos atenienses - como ficou conhecido este grupo - foram responsáveis por uma espécie de regeneração intelectual em São Luís. Eles não configuraram uma unidade política coesa, no entanto exerceram atividades literárias evocando o passado mítico da Atenas Brasileira, com um forte viés ufanista. Para tanto escreviam para jornais, publicavam livros, exerciam cargos públicos e lecionavam em escolas e universidades. Dito isto, se faz necessária a compreensão dos motivos dos batismos dos logradouros com os nomes ligados a intelectualidade.

Nas últimas décadas do século XIX e durante todo o século XX, o poder público agiu, via publicação de resoluções e leis, de forma a homenagear personalidades do Maranhão através de batismos de logradouros e da construção de monumentos. Essas ações tiveram como consequência principal a duplicidade de nomes para um mesmo logradouro.

A imposição de nomes por parte do poder público funcionou em alguns casos, mas em outros a força da memória popular coletiva através do uso cotidiano do nome antigo do logradouro se sobressaiu. São alguns exemplos de batismos impostos que perduram até hoje: Rua Humberto de Campos (antiga 
Travessa Vira Mundo), Praça João Lisboa (antiga Praça da Liberdade), Rua Lúcio de Mendonça (antiga Rua dos Pescadores) e Travessa Silva Jardim (antiga Travessa Curupira). Constituem exemplos de nomeações impostas que não vingaram: Rua Cândido Mendes (atual Rua da Estrela), Rua Aluisio Azevedo (atual Rua das Flores), Rua Henriques Leal (atual Rua Direita) e Rua Paula Duarte (atual Rua do Ribeirão).

O ato de nomeação dos logradouros, seja pelos habitantes do lugar ou pelos que estão no poder, nos ajudam a compreender mais sobre a história do lugar e assim preservar uma memória. Pierre Nora, ao diferenciar memória e História, forja o termo "lugares de memória", que são como restos, resquícios de um passado que deve ser cristalizado em formas, como monumentos e símbolos. Para Nora (1993, p. 13), "os lugares da memória nascem e vivem do sentimento que não há uma memória espontânea, que é preciso criar arquivos, manter aniversários, organizar celebrações (...) pois sem vigilância comemorativa, a história depressa os varreria”.

Os lugares de memória em São Luís começaram a se formar em torno do mito da Atenas Brasileira através da ereção de monumentos e da nomeação de logradouros em homenagem e reverência aos integrantes do Grupo Maranhense, como Gonçalves Dias, Odorico Mendes e João Lisboa.

Em 1873 foi inaugurada no Largo dos Remédios, a estátua do poeta Gonçalves Dias. Vinte e sete anos depois de instalado o monumento, o nome de Largo dos Remédios foi substituído pela denominação de Praça Gonçalves Dias. Foram plantadas no espaço da praça diversas palmeiras imperiais, em homenagem a um dos mais conhecidos poemas do autor e da língua portuguesa: Canção do Exílio. 


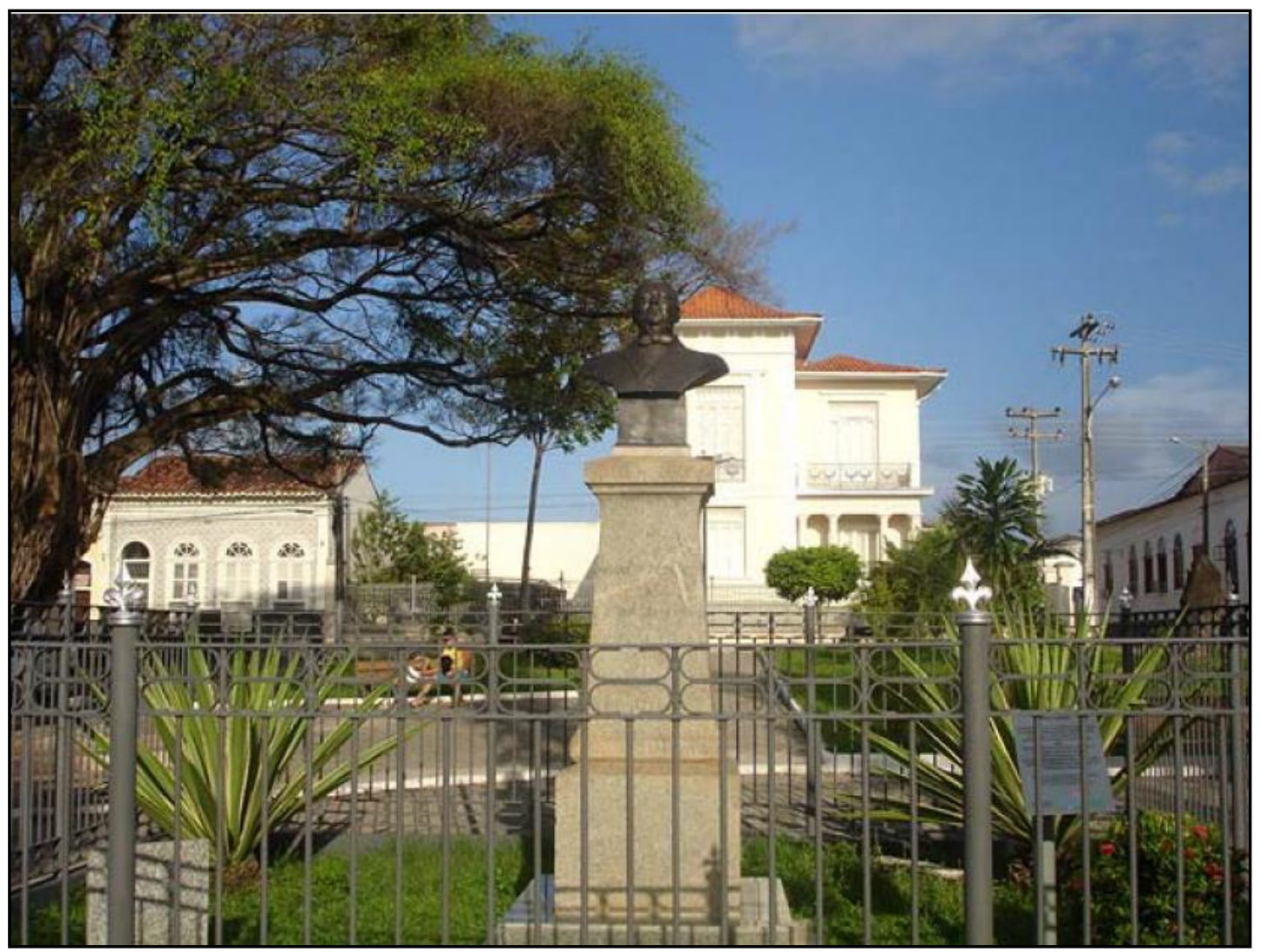

Figura 5. Praça Odorico Mendes com seu respectivo busto.

Fonte: Borralho (2009).

A denominação de Praça Odorico Mendes (Figura 5) foi dada pela Câmara Municipal de São Luís em 28 de julho de 1901 pela Resolução no. 14, a mesma que criou a Praça João Lisboa (BORRALHO, 2019). O busto em homenagem a Odorico Mendes foi inaugurado na praça em 1905, uma obra realizada pelo escultor mexicano José Maria Oscar Rodolfo Bernardelli.

Foi por meio de uma lei Estadual, que houve a autorização para a construção do monumento em homenagem à João Lisboa, de autoria do escultor francês Jean Magrou e que viria a ser inaugurado no ano de 1918. Para Claval (2001, p. 202), “nomear lugares é impregná-los de cultura e poder”. A cidade é um lugar onde se inscrevem essas marcas do poder, ela é como um palimpsesto, cada demolição, cada nome de rua ou praça que se foi, ressurge pela lembrança, ou se revela através de um signo que permanece capaz de fazer aflorar, de recompor na memória o que foi. 
Por isso toda construção ou monumento inserido no espaço urbano é capaz de expressar um pensamento, um sentimento, pois é dotado de uma simbologia, que por sua vez comporta representações múltiplas sobre relações de poder. Para Foucault (2014, p. 45), o que faz com que "o poder se mantenha e que seja aceito é simplesmente que ele não pesa só como uma força que diz não, mas que de fato ele permeia, produz coisas, induz ao prazer, forma saber, produz discurso". Desta forma, houve por parte da população de São Luís uma aceitação imediata dos monumentos e dos nomes dos logradouros, não só do Grupo Maranhense, mas de tantos outros intelectuais dos séculos XIX e XX, já que isso era uma forma se orgulhar desta terra "singular" e "distinta", produtora de nobres personagens ligados às letras.

Neste contexto a noção de identidade é bem importante, Hall (2006) ao discorrer sobre identidades nacionais afirma que elas são formadas e transformadas no interior de uma representação. Assim, as pessoas não são apenas cidadãs de uma nação, mas participam de uma ideia de nação. Para o autor, "uma cultura nacional é um discurso, um modo de construir sentidos (...) as culturas nacionais, ao produzir sentidos sobre 'a nação', sentidos com os quais podemos nos identificar, constroem identidades" (HALL, 2006, p. 50-51). Tais sentidos são revelados através de estórias que são contadas sobre a nação, que une passado e presente pelas imagens que construíram dela.

A concepção de Hall sobre identidades nacionais pode ser transposta a uma identidade local em São Luís. Aqui a elite política e intelectual construiu uma ideia mítica de Atenas Brasileira, ideia esta atrelada a um sentimento de valorização da sociedade e do território maranhense perante o Brasil. 0 sentimento ufanista em São Luís se alastrou e ficou impregnado no imaginário da população por muito tempo, os ludovicenses se orgulhavam até recentemente de outros dois mitos criados pelo élan da Atenas Brasileira e seus desdobramentos: o de melhor português falado no Brasil e de única capital brasileira fundada por franceses.

A criação da identidade ligada aos intelectuais e escritores em São Luís está gravada nos monumentos e logradouros do Centro antigo, lugares marcados, tantas vezes impostos como símbolos, para serem lembrados, perpetuados através de uma memória que se afasta e "inutiliza a crítica do passado" 
(COSTA, 2006 apud AZEVEDO, 2006, p. 13). Mas também existem as micro-identidades que negam a imposição de nomes ligados ao poder político e intelectual, já que nada respondem a certos grupos.

\section{CONSIDERAÇÕES FINAIS}

Este ensaio, ainda que preliminar, buscou chamar atenção sobre como se formou a toponímia de logradouros na área central de São Luís. As nomeações dos lugares e das categorias da paisagem permitem falar muito sobre o território, nem que para isso se construam estórias inventadas, forjadas pelos grupos com intuito de criar e perpetuar uma memória, seja ela de natureza religiosa ou mesmo sociopolítica. Há, portanto, uma transformação de um universo físico em um universo social.

Os nomes dos logradouros públicos não são somente um meio de referência local, mas têm a ver com um contexto específico cultural e também de relações de poder, simbolizados a partir das vontades e anseios nem sempre harmoniosos entre os habitantes que vivem e respiram o lugar e os que estão no poder.

Os monumentos religiosos e sua toponímia, como santos e igrejas, são antigos no lugar central da capital maranhense, pois possuem uma significação sagrada para os habitantes do lugar, são territórios simbólicos reivindicados, vivenciados e praticados no cotidiano através da fé do grupo que utiliza o lugar. A toponímia ligada ao hagiológio católico é, indubitavelmente, uma herança da colonização portuguesa em São Luís.

Durante os séculos XIX e XX, os logradouros centrais perderam uma identidade atrelada ao caráter físico e passaram a ter um significado cultural, principalmente nomeações ligadas aos intelectuais e homens das letras. Este processo só foi possível pelo apoio incondicional do poder público. Na realidade os intelectuais se confundiam com os homens do poder, já que muitos deles exerciam cargos públicos administrativos de confiança. 
Os antropotopônimos relacionados ao mito da Atenas Brasileira se sobressaem em um universo plural de nomeações de natureza física e mais ainda de taxonomias antropoculturais, já que foram fundados enquanto representação de identidades em contexto histórico específico.

É preciso entender que as nomeações de praças, ruas, largos, becos e travessas na área de ocupação mais antiga de São Luís são, amiúde, um ato de poder, sempre imposto, nem sempre consentido pela população, embora fundador de identidades, narrativas e discursos, que precisam ser analisados de forma crítica.

\section{REFERÊNCIAS}

AMARAL, J. R. O Maranhão Histórico. São Luís: Instituto Géia, 2003. 121p.

BORRALHO, J. H. P. A Athenas Equinocial: a fundação de um Maranhão no Império brasileiro. 2009. 334f. Tese

(Doutorado em História) - Departamento de História, Universidade Federal Fluminense, Niterói, 2009.

CHOAY, F. A Alegoria do Patrimônio. 4. ed. São Paulo: Estação Liberdade/Editora UNESP, 2006. 288p.

CLAVAL, P. A Geografia Cultural. 2. ed. Florianópolis: EDUSC, 2001. 453p.

CORRÊA, R. Formação Social do Maranhão: o presente de uma arqueologia. São Luís: Sioge, 1993. 391p. . Atenas Barsileira: mito e realidade. Suplemento Cultural e Literário Guesa Errante. São Luís, Ano X, Edição 258, 2012. Disponível em: <http://www.guesaerrante.com.br/2012/9/26/atenas-brasileira-mito--realidade 3347.htm>. Acesso em 11 jul. 2015.

COSTA, W. C. Omnia Vanitas: uma radiografia do poder oligárquico (prefácio). In: AZEVEDO, Emílio. 0 caso do Convento das Mercês: as marcas do atraso político e a ilegalidade envolvendo o patrimônio público. São Luís: Lithograf, 2006. 209p.

DI TIZIO, I. R. Tietê ontem e hoje: preservação ou mudança toponímica e a legislação do ato de nomear. Uma proposta de Lei. 2007. 203 f. Tese (Doutorado em Semiótica e Linguística Geral). Faculdade de Filosofia, Letras e Ciências Humanas, USP, São Paulo, 2007.

DICK, M. V. P. A. Motivação Toponímica e a realidade brasileira. São Paulo: Arquivo do Estado, 1990. 387p.

. Toponímia e Antroponímia no Brasil. Coletânea de estudos. São Paulo: Gráfica da FFLCH/USP, 1992. 258p.

FERRARA, L. D. As Mascaras da Cidade. Dossiê Cidades, São Paulo, n.5, p. 3-10, mar/mai, 1990.Disponível em:<http://www.usp.br/revistausp/n5/flucrecia.texto.html.>. Acesso em 8 jul. 2015.

FOUCAUlT, M. Microfísica do Poder. 28. ed. Rio de Janeiro: Paz e Terra, 2014. 431p.

GOHN, M. G. Teoria dos Movimentos Sociais. 6. ed. São Paulo: Loyola, 2006. 381p. 
GOMES, J. T. P. Síntese Histórica da Formação Urbana de São Luís. Revista FIPES, São Luís, n. 2, v. 3, p. 17-25, jul/dez, 1988.

GULlaR, F. Poema Sujo. 12. ed. Rio de Janeiro: José Olympio, 2009. 74p.

HAESBAERT, R. Identidades Territoriais. In: CORREAA, R. L.; ROSENDAHL, Z. (Orgs.). Manifestações da Cultura no Espaço. Rio de Janeiro: EdUERJ, 1999. (Série Geografia Cultural). 248p. p. 169-190.

HALL, S. A identidade cultural na pós-modernidade. 11. ed. Rio de Janeiro: DP\&A, 2006. 102p.

HOLZER, W. Uma discussão fenomenológica sobre os conceitos de Paisagem e Lugar, Território e Meio Ambiente. Revista Território, Rio de Janeiro, n. 3, Ano II, jul/dez, 1997. Disponível em:

http://www.revistaterritorio.com.br/pdf/03_6_holzer.pdf. Acesso em 10 jul. 2015.

ISQUERDO, A. N. O Fato Lingüístico como Recorte da Realidade Sócio-Cultural. 1996. 409 f. Tese (Doutorado em Letras). Faculdade de Ciências e Letras, Universidade Estadual Paulista, Araraquara, 1996.

LACROIX, M. L. L. A fundação francesa de São Luís e seus mitos. 3. ed. São Luís: Editora UEMA, 2008. 184p.

LEITE, A. F. O Lugar: Duas acepções geográficas. Anuário do Instituto de Geociências - UFRJ. Rio de Janeiro, v. 21 , p. 9-20, 1998. Disponível em: <http://www.igeo.ufrj.br/anuario_1998/vol21_09_20.pdf>. Acesso em 07 jul. 2015.

NORA, P. Entre memória e História: a problemática dos lugares. Projeto História, São Paulo, n. 10, dez. 1993. Disponível em: http://revistas.pucsp.br/index.php/revph/article/viewFile/12101/8763. Acesso em 05 jul. 2015.

OLIVEIRA, E. G. Os Novos Atenienses: saudade e poesia como invenção do Maranhão. Ciências Humanas em Revista, São Luís, v. 5, número especial, p. 135-144, jun. 2007.

RIBEIRO JUNIOR, J. R. B. Formação do espaço urbano de São Luís: 1612-1991. São Luís: Ed. do Autor / FUNC, 2001. $154 \mathrm{p}$.

ROSENDHAL, Z. Território e territorialidade: uma perspectiva geográfica para o estudo da religião. In: ROSENDHAL, Z.; CORRÊA, R. L. Geografia: Temas sobre cultura e espaço. Rio de Janeiro: EdUERJ, 2005. (Série Geografia Cultural), 226 p. p. 191-226.

SANTOS, M. Por uma outra Globalização: do pensamento único à consciência universal. Rio de Janeiro: Record, 2000. $176 \mathrm{p}$.

SANTOS, M. e SILVEIRA, M. L. O Brasil: Território e sociedade no início do século XXI. Rio de Janeiro: Record, 2001. $490 \mathrm{p}$.

TUAN, Yi Fu. Espaço e Lugar: a perspectiva da experiência. Londrina: EdUEL, 2013. 248p. 